\title{
Bronchogenic cyst of the ileal mesentery: a case report and a review of literature
}

\author{
Adolfo Petrina ${ }^{1 *}$, Carlo Boselli ${ }^{1}$, Roberto Cirocchi ${ }^{2}$, Piero Covarelli ${ }^{1}$, Emilio Eugeni ${ }^{1}$, Marco Badolato ${ }^{1}$, Luigi Finocchi ${ }^{1}$, \\ Stefano Trastulli ${ }^{2}$, Giuseppe Noya ${ }^{1}$
}

\begin{abstract}
Introduction: Bronchogenic cyst is a rare clinical entity that occurs due to abnormal development of the foregut; the majority of bronchogenic cysts have been described in the mediastinum and they are rarely found in an extrathoracic location.
\end{abstract}

Case presentation: We describe the case of an intra-abdominal bronchogenic cyst of the mesentery, incidentally discovered during an emergency laparotomy for a perforated gastric ulcer in a 33-year-old Caucasian man.

Conclusions: Bronchogenic cyst should be considered in the differential diagnosis of subdiaphragmatic masses, even in an intraperitoneal location.

\section{Introduction}

The laryngotracheal groove appears at the end of the third week of gestation in the embryonic foregut [1]; the dorsal portion of the foregut elongates to form the esophagus, and the ventral portion ultimately differentiates into the respiratory tract, with ciliated epithelium lining both the fetal esophagus and trachea [1-3]. Bronchogenic cyst and esophageal duplications are clinical malformations due to abnormal development of the foregut.

Bronchogenic cysts form from accessory ventral buds arising from the foregut distal to the future lung at about the fifth week of intra-uterine life; the majority of bronchogenic cysts have been described in the mediastinum $(90 \%$, most commonly in the posterior aspect of the superior mediastinum [4-8]) and they are rarely found in an extrathoracic location; a small number of them have been reported in abdominal location, with prevalence in the retroperitoneal space [9-12].

We report a bronchogenic cyst incidentally discovered as a small intra-peritoneal mass in our patient, who was admitted to our surgical unit for acute abdominal pain due to gastric ulcer perforation.

\footnotetext{
* Correspondence: adolfo.petrina@poste.it

${ }^{1}$ General and Oncological Surgery Unit, University of Perugia, Perugia, Italy Full list of author information is available at the end of the article
}

\section{Case report}

Our patient, a 33-year-old Caucasian man, was referred to our institution for acute abdominal pain; the symptoms had begun two days earlier as a mild epigastric pain that localized the following day in the right iliac fossa. He had no instances of nausea or vomiting at admission, a body temperature of $37.2^{\circ} \mathrm{C}$, a white blood cell count of 20.30 cells $/ \mathrm{mm}^{3}$ (polymorphonuclear leukocytes $84.6 \%$ ) and sluggish peristalsis. He had a history of misuse of a non-steroidal anti-inflammatory drug (NSAID) used to manage his back pain without any medical prescription.

Plain X-rays of his abdomen did not show pneumoperitoneum or fluid levels; plain X-rays of his chest were also normal. An abdominal ultrasound scan showed a $3.2 \mathrm{~cm}$ pre-aortic mass and some fluid in the Douglas pouch (Figure 1).

Our patient underwent a laparotomy, which revealed some purulent fluid with mild inflammation of the appendix; the jejunum and ileus were normal. An exploration of the supramesocolic space revealed a gastric perforation of the anterior wall just before the duodenum (Figures 2 and 3).

An appendectomy and suture ligation of the gastric ulcer was performed. Arising from the ileal mesentery was a $5 \mathrm{~cm}$ spherical brown mass that on histological examination was revealed to be a bronchogenic cyst (a cyst lined with pseudostratified columnar and ciliated 


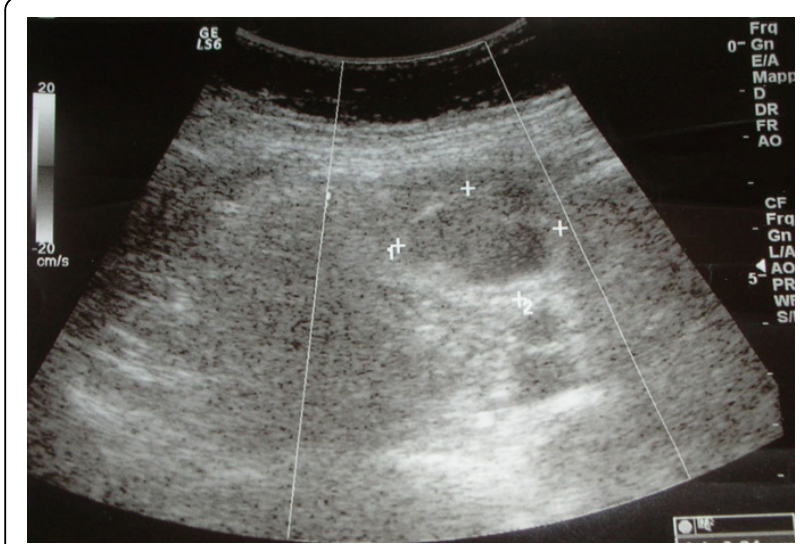

Figure 1 Ultrasonography showing a $3.2 \mathrm{~cm}$ pre-aortic mass cuboidal epithelium, with a wall of smooth muscle bundles and mucinous glands) (Figures 4 and 5).

Our patient was discharged on the twelfth post-operative day.

\section{Discussion}

Bronchogenic cysts originate from an accessory lung bud of the primitive foregut after the third week of embryonic life. Most commonly they migrate caudally with the esophagus and are eventually found in the posterior mediastinum near the carina, attached to the tracheobronchial tree or to the esophagus. Rarely the cyst may separate completely from its origin and may be found in unusual sites, such as pericardium, skin $[13,14]$ or in intra-spinal locations. Most bronchogenic cysts are

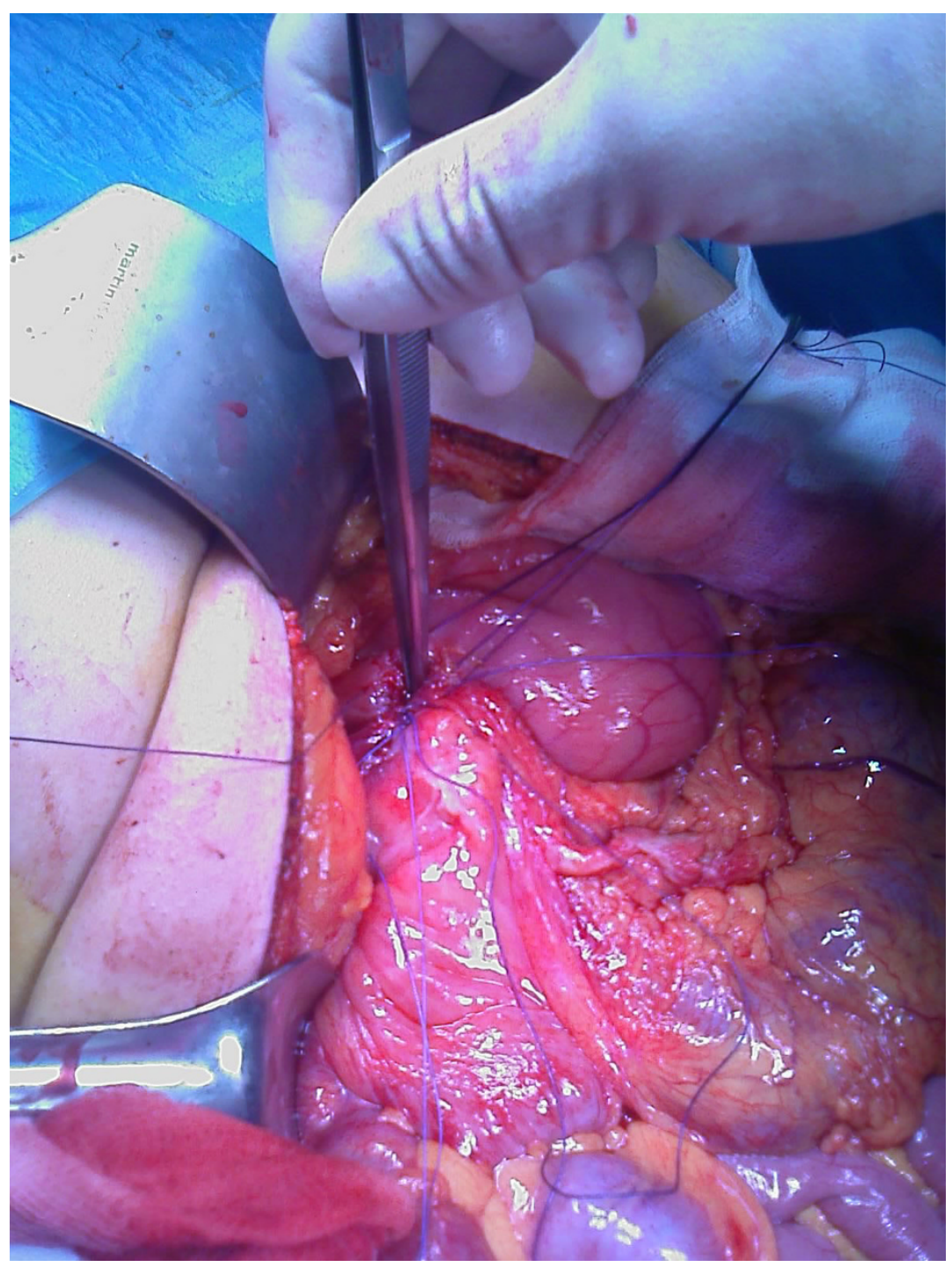

Figure 2 Perforated gastric ulcer. 


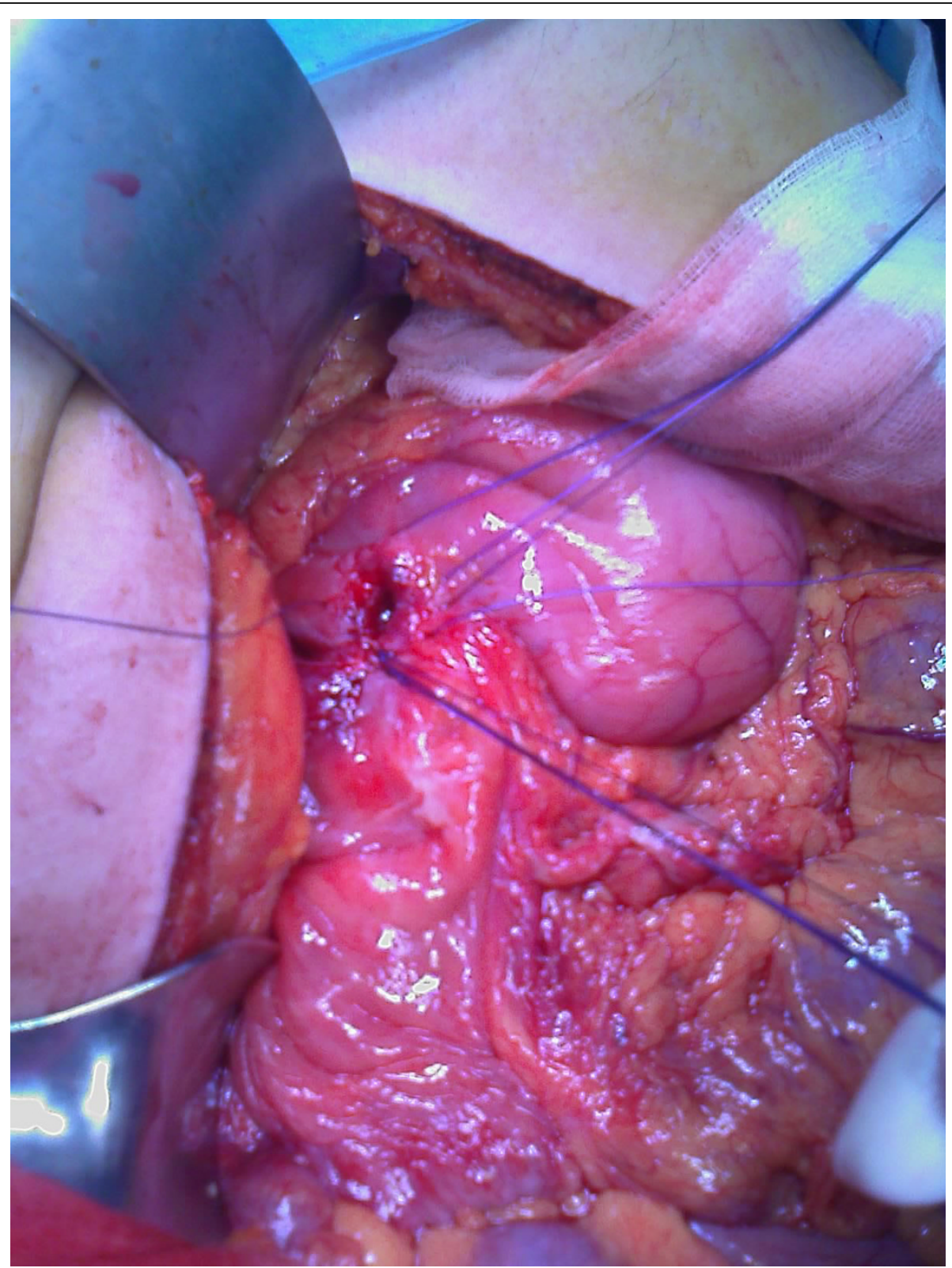

Figure 3 Perforated gastric ulcer before suture ligation.

small and are usually discovered incidentally because patients are asymptomatic, though sometimes there can be epigastric or left upper quadrant abdominal pain. Malignant transformation is rare [15].

A subdiaphragmatic location is extremely rare, with only about 20 cases reported in the literature [13-19]. This is due to the migration of the cyst prior to the fusion of the pleuroperitoneal membrane. Our patient's cyst was unilocular and arose from the ileal mesenterium, and was filled with mucin.

\section{Conclusion}

Bronchogenic cyst should be considered in the differential diagnosis of subdiaphragmatic masses, even in intraperitoneal location.

\section{Consent}

Written informed consent was obtained from the patient for publication of this case report and any accompanying images. A copy of the written consent is available for review by the Editor-in-Chief of this journal. 

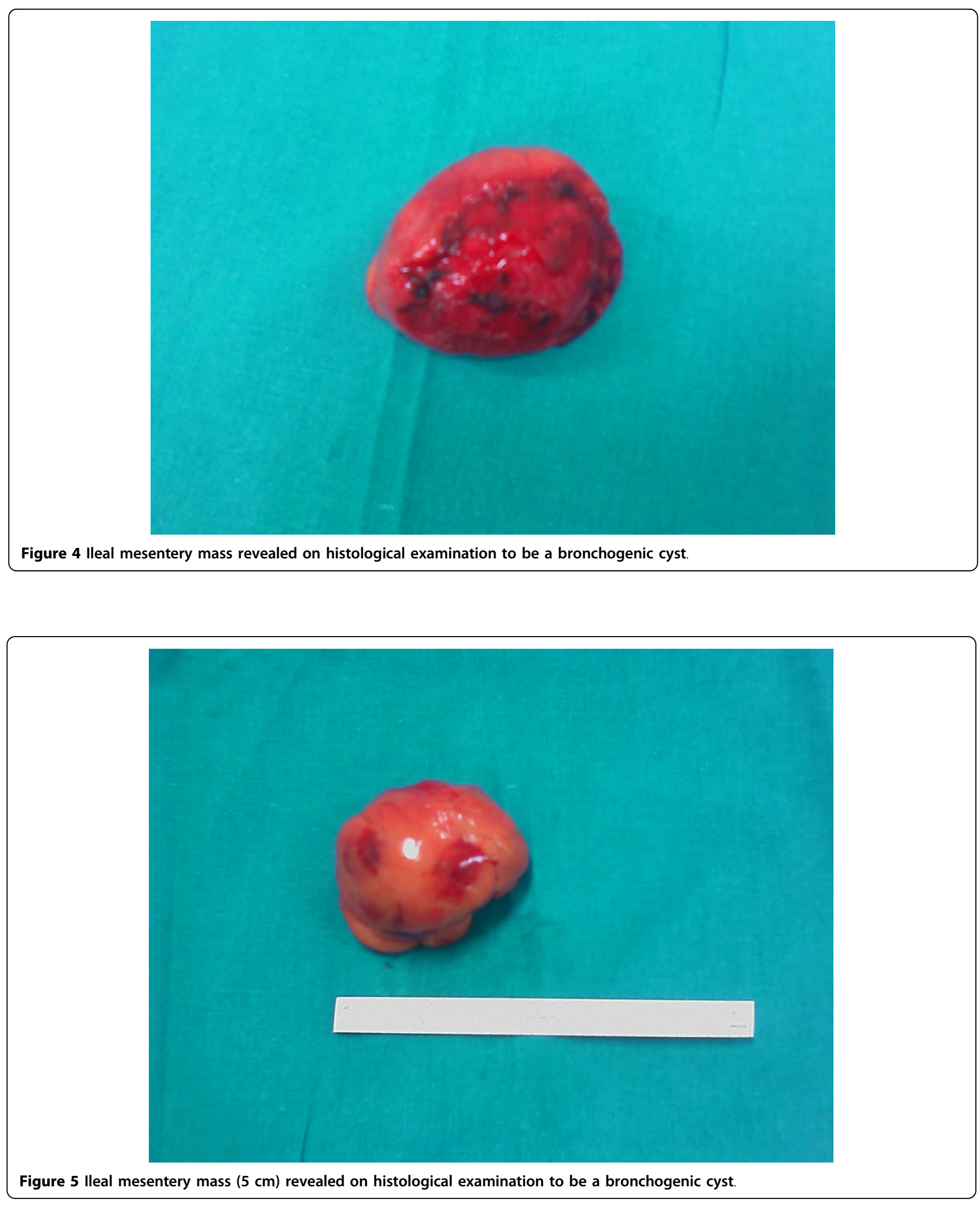


\section{Acknowledgements}

Thanks to Maria Antonietta Ricci MD and to Nancy Hardies for their critical revisions of the manuscript.

\section{Author details}

${ }^{1}$ General and Oncological Surgery Unit, University of Perugia, Perugia, Italy. ${ }^{2}$ Emergency and General Surgery Unit, University of Perugia, Terni, Italy.

\section{Authors' contributions}

AP analyzed and interpreted the data from our patient; $C B$ and EE were major contributors to the writing of the manuscript. All authors read and approved the final manuscript

\section{Competing interests}

The authors declare that they have no competing interests.

Received: 15 February 2010 Accepted: 23 September 2010

Published: 23 September 2010

\section{References}

1. Skandalakis JE, Gray SW, Ricketts R: The esophagus. In Embryology for Surgeons. Edited by: Skandalakis JE, Gray SW. Baltimore, MD: Williams and Wilkins, 2 1994:65-112.

2. Moore TE, Parson : The developing human. Clinically Oriented Embryology Philadelphia, PA: WB Saunders, 5 1993, 628-644.

3. DeLorimier AA: Congenital malformations and neonatal problems of the respiratory tract. In Pediatric Surgery. Edited by: Welch KJ, Randolph JG, Ravitch MM, et al. Chicago, IL: Yearbook Medical Publishers, 4 1986:631-648.

4. Laberge JM, Puligandla $\mathrm{P}$, Flageole $\mathrm{H}$ : Asymptomatic congenital lung malformations. Semin Pediatr Surg 2005, 14:16-33.

5. Chen CC: Bronchogenic cyst in the interatrial septum with a single persistent left superior vena cava. J Chin Med Assoc 2006, 69:89-91.

6. Ibanez Aguirre J, Marti Cabane J, Bordas Rivas JM, Valenti Ponsa C, Erro Azcarate JM, De Simone P: A lump in the neck: cervical bronchogenic cyst mimicking a thyroid nodule. Minerva Chir 2006, 61:71-72.

7. Ustundag E, Iseri M, Keskin G, Yayla B, Muezzinoglu B: Cervical bronchogenic cysts in head and neck region. J Laryngol Otol 2005, 119:419-423.

8. Ozel SK, Kazez A, Koseogullari AA, Akpolat N: Scapular bronchogenic cysts in children: case report and review of the literature. Pediatr Surg Int 2005, 21:843-845.

9. Liang MK, Yee HT, Song JW, Marks JL: Subdiaphragmatic bronchogenic cysts: a comprehensive review of the literature. Am Surg 2005, 71:1034-1041.

10. Jo WM, Shin JS, Lee IS: Supradiaphragmatic bronchogenic cyst extending into the retroperitoneum. Ann Thorac Surg 2006, 81:369-370.

11. Hedayati N, Cai DX, McHenry CR: Subdiaphragmatic bronchogenic cyst masquerading as an "adrenal incidentaloma". J Gastrointest Surg 2003, 7:802-804

12. Ingu A, Watanabe A, Ichimiya $Y$, Saito $T$, Abe $T$ : Retroperitoneal bronchogenic cyst: a case report. Chest 2002, 121:1357-1359.

13. Reichelt O, Grieser T, Wunderlich H, Moller A, Schubert J: Brochogenic cyst: a rare differential diagnosis of retroperitoneal tumors. Urol Int 2000, 64:216-219.

14. Zvulunov A, Amichai B, Grunwald MH, Avinoach I, Halevy S: Cutaneous bronchogenic cyst: delineation of a poorly recognized lesion. Pediatr Dermatol 1998, 15:277-281.

15. Sullivan SM, Okada S, Kudo M, Ebihara Y: A retroperitoneal bronchogenic cyst with malignant change. Pathol Int 1999, 49:338-341.

16. Braffman B, Keller R, Stein Gendal E, Finkel SI: Subdiaphragmatic bronchogenic cyst with gastric communication. Gastrointest Radiol 1988, 13:309-311.

17. Haddadin WJ, Reid R, Jindal RM: A retroperitoneal bronchogenic cyst: a rare cause of a mass in the adrenal region. J Clin Pathol 2001, 54:801-802.

18. Foerster HM, Sengupta EE, Montag AG, Kaplan EL: Retroperitoneal bronchogenic cyst presenting as an adrenal mass. Arch Pathol Lab Med 1991, 115:1057-1059.
19. Sauvat F, Fusaro F, Jaubert F, Galifer B, Revillon Y: Paraesophagea bronchogenic cyst: first case reports in pediatric. Pediatr Surg Int 2006, 22:849-851.

doi:10.1186/1752-1947-4-313

Cite this article as: Petrina et al:: Bronchogenic cyst of the ileal mesentery: a case report and a review of literature. Journal of Medical Case Reports 2010 4:313.

\section{Submit your next manuscript to BioMed Central and take full advantage of:}

- Convenient online submission

- Thorough peer review

- No space constraints or color figure charges

- Immediate publication on acceptance

- Inclusion in PubMed, CAS, Scopus and Google Scholar

- Research which is freely available for redistribution

Submit your manuscript at www.biomedcentral.com/submit
C Biomed Central 